\title{
The Effect of Fundamental Factors on Stock Returns at Insurance Companies on the Indonesia Stock Exchange
}

\author{
Galuh Ayu Arghi Prameshti and Augustina Kurniasih \\ Department of Magister Management, Faculty of Postgraduate Program, \\ Mercu Buana University, Jakarta, Indonesia
}

\begin{abstract}
This research was aims to analyze fundamental factors that effect stock return of insurance companeis listed on the Indonesia Stock Exchange. Sample of this research was 12 insurance companies that listed on the Indonesia Stock Exchange. The sample selection procedure is purposive sampling, this method has criteria that set by researcher. The number of population for this research is 14 companies and the number of sample that examined after passing the purposive sampling method is 12 companies. Independent variables that used in this research are EPS, PER, ROE, DAR, NPM, PBV, RBK, RPP, TATO, DER and stock return as a dependent variable. The results of this study prove that the model is built accordingly. Individually there is a significant influence from DAR, PBV, RBK on stock returns of insurance companies.
\end{abstract}

Key words: Stock returns, panel data, profitability ratios, leverage ratios, market value ratios, assets management ratios, operational ratios, insurance companies, EPS, PER, ROE, DAR, NPM, PBV, RBK, RPP, TATO, DER

\section{INTRODUCTION}

On these days, society are more aware of the importance of risk transferring by buying insurance. Therefore, there are a lot of insurance companies that established and they are trying to attract the society credence in transferring risk to their insurance companies. Majority of insurance companies are conventional companies whom selling sharia product as their unit. To regulate insurance companies, government launch Law No. 40 Year 2014 which supported with Financial Services Authority Regulation No. 67/POJK.05/2016 regarding Licensing and Institution of Insurance Company, Sharia Company, Reinsurance Company and Sharia Insurance Company. Article 17 clause 1 POJK No. 67/POJK.05/2016 which stated that an insurance company and a reinsurance company must carry out separation of sharia unit and make it a sharia insurance company or a sharia reinsurance company the tabarru' fund and investment fund of the participants has reached at least $50 \%$ of the total value of the insurance fund, tabarru' fund and investment fund of participants in the parent company or 10 years, since, the promulgation of Law No. 40 of 2014 on Insurance.

This regulation encourages the advancement of insurance industry in Indonesia and based on Indonesia Stock Exchange, we could see that the stock returns are growing fluctuating and tends to fallin (Fig. 1).

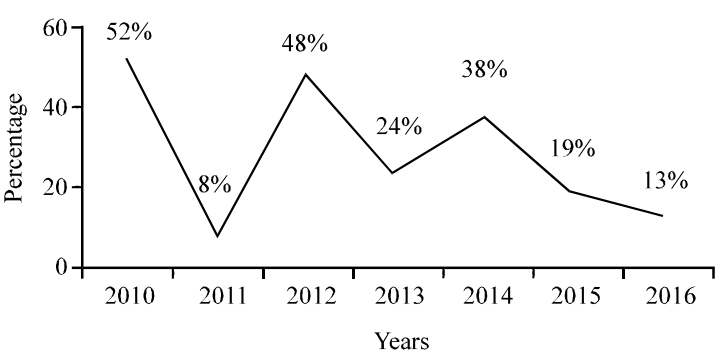

Fig. 1: Average of stock returns of insurance companies from 2010-2016

The stock returns that are keep falling obviously is not good news for the investors and the potential investors. For this reason, researcher trying to find out the factors that influence the stock return of insurance companies.

Based on the several research, there are a lot of inconsistency of the result. The result of Astuti (2013) was EPS has a negative effect but it is not significant to stock retuns, however, Gunadi and Kesuma (2015) and Nesa (2015) found that EPS has a positive significant effect to stock returns.

Astuti (2013) found that PER and DER has a positive effect but it is not significant to stock returns. This study is contradictory with Nesa (2015) whom found that PER has a negative effect but it is not significant to stock

Corresponding Author: Galuh Ayu Arghi Prameshti, Department of Magister Management, Faculty of Postgraduate Program, Mercu Buana University, Jakarta, Indonesia 
return and Gunadi and Kesuma (2015) whom found that DER has a negative significant effect to stock return.

In the other hand, researcher also found out that there is an inconsistency in a previous studied, the result of Amalia (2017) are ROE has a positive significant effect, DAR and NPM has a negative significant effect, meanwhile $\mathrm{PBV}$ and RBK has a positive significant effect, RPP and TATO has a negative significant effect to stock returns. This studied also contravene with Rita et al. (2014) whom found that ROE has a positive effect but it is not significant and TATO has a positive significant effect to stock return. However, Anwaar (2016) found that NPM has a positive significant effect to stock returns. Meanwhile, Nesa (2015) found that PBV has a negative effect but it is not significant to stock returns. Siswandaru (2006) found that RPP has a negative significant effect to stock price in insurance companies and Ngaisah (2008) found that DAR has a positive significant effect to stock returns. Therefore, researcher trying to find out the effect of fundamental factors on stock returns at insurance companies.

The aims of this study is to analyze the effect of Earning Per Share (EPS), Price Earning Ratio (PER), Return on Equity (ROE), Debt to Assets Ratio (DAR), Net Profit Margin(NPM), Price per Book Value (PBV), Ratio of Claim Expense (RBK), Ratio of Premium Growth (RPP), Total Assets Turn Over (TATO), dan Debt Equity Ratio (DER) to stock returns at insurance companies on the Indonesia Stock Exchange.

\section{Literature review}

Risk and return: According to Irham and Hadi (2009), risk and return is a condition of the companies, institutions or individual in order to making an investment decision, both loss and gain in an accounting period. In the investment, risk and return are knows have a strong connection. Where if an investment has a high risk the the investment will has a high return as well, however, if the investment has a low risk, then the investment will have a low return.

Signaling theory: According to Irham and Hadi (2009), signaling theory is a theory that seeking a sign about company conditions which describe a company. Signaling theory also can be said as a theory which discuss ups and down of the stock price in the market, it would give an effect to investor's decision.

Stock return: According to Gautam (2017), stock return is a return of investment provides over a period of time. Source of this stock return can include dividends, return of capital and capital appreciations. Annual of the stock return as calculate by margins between closing price at the $t$ period an closing price at the $\mathrm{t}-1$ period divided by closing price at the $\mathrm{t}-1$ period.

Capital Assets Pricing Model (CAPM): According to Eduardus (2001), CAPM describe the relationship between risk and return in a simple way and using only one variable, that is beta to describe the risk. Likewise, CAPM also use to find out internal factor that affecting stock return on the company in the other hand, APT is for find out external factors that affecting stock return on the company.

Asymmetric information: Asymmetric information is a condition where there are problem of communication between company and investor (Rahmawati, 2012). This condition showed that there is one party whom have a more information rather than the others regarding company condition. Asymmetric information has to be minimized in order to support the transparency of the information provided by company to the potential investors.

Profitability ratios: Profitability ratio is used to measure the effectivity of a company in gather the profit. The higher profit that company get as better as the management in managing the company (Sutrisno, 2000). Variables that used here are Net Profit Margin (NPM), Return on Equity (ROE), Earning Per Share (EPS).

Leverage ratios: Leverage ratio is show how big company used their debt for company's operational. if company does not have a debt, factor of the leverage will be 0 (zero) which means that all the company funds are come from equity. The lower leverage factor, the smaller of the company risk in order to economy's weaken. Variables that used here are Debt to Asset Ratio (DAR), Debt Equity Ratio (DER).

Market value ratios: Market value ratio is used to measure the company (Suad and Pudjiastuti, 2015). Variables that used here are Price Earnings Ratio (PER), Price Book Value (PBV).

Assets managements ratios: This ratio is use for measure company's effectivity in order to manage their asset (Suad and Pudjiastuti, 2015). Variable that used here is Total Asset Turnover (TATO).

Operational ratios: According to Noor (2014), operational ratio is an uncertainty of a revenue cashflow during the 
business. The more uncertainty of the investment fund, the higher risk of that investment. Variables that used here are Ratio of Claim Expense (RBK), Ratio of Premium Growth (RPP).

Hypothesis: Hypothesis on this research are:

. $\quad H .=$ EPS has a positive significant effect to stock return

- $H_{.}=$PER has a positive significant effect to stock return

- $\mathrm{H}_{\mathrm{r}}=\mathrm{ROE}$ has a positive significant effect to stock return

- $\quad H .=$ DAR has a negative significant effect to stock return

- $\quad H .=$ NPM has a positive significant effect to stock return

- $\quad H_{.}=$PBV has a positive significant effect to stock return

. $\quad H .=R B K$ has a negative significant effect to stock return

- $H_{.}=$RPP has a negative significant effect to stock return

- $\mathrm{H}_{\mathrm{r}}=\mathrm{TATO}$ has a positive significant effect to stock return

- $\quad H_{.}=$DER has a negative significant effect to stock return

\section{MATERIALS AND METHODS}

This research using a panel data which contains cross-section and time series data. With purposive sampling, we have 12 insurance companies listed on the Indonesia Stock Exchange that pass the criteria, 12 sample of insurance companies (cross section) in a period 2014-2017 (time series). Variables in this research are:

- Dependent variable: stock return

- Independent variables: EPS, PER, ROE, DAR, NPM, PBV, RBK, RPP, TATO, DER

The measurement of each variables are: Stock return:

$$
\text { Return }=\frac{\text { Closing price }_{\mathrm{t}}-\text { Closing price }_{\mathrm{t}-1}}{\text { Closing price }_{\mathrm{t}-1}}
$$

EPS:

$$
\mathrm{EPS}=\frac{\text { Earning after tax }}{\text { Average outsanding shares }}
$$

PER:

$$
\text { PER }=\frac{\text { Stock market price }}{\text { Earning per share }}
$$

ROE:

$$
\mathrm{ROE}=\frac{\text { Net income }}{\text { Equity }} \times 100 \%
$$

DAR:

$$
\mathrm{DAR}=\frac{\text { Total debt }}{\text { Total asset }} \times 100 \%
$$

NPM:

$$
\mathrm{NPM}=\frac{\text { Net profit }}{\text { Revenue }} \times 100 \%
$$

PBV:

$$
\mathrm{PBV}=\frac{\text { Price per share }}{\text { Book value of equity }}
$$

RBK:

$$
\mathrm{RBK}=\frac{\text { Claim charge }}{\text { Premium revenue }}
$$

RPP:

$$
\mathrm{RPP}=\frac{\text { Difference of premium }}{\text { Premium net to on thelast period }}
$$

TATO:

$$
\mathrm{TATO}=\frac{\text { Total sales }}{\text { Total asset }}
$$

DER:

$$
\mathrm{DER}=\frac{\text { Total debts }}{\text { Equity }} \times 100 \%
$$

This research using a secondary data from the summary of the company's performance that obtained from Indonesian Stock Exchange website. Stock return are obtained by downloading monthly closing price each year on the website.

This data is analyze with descriptive statistics and inferential statistics. Inferential statistics are used to get the answer of the hypothesis that were made by the researcher through regression of data panel.

\section{RESULTS AND DISCUSSION}

\section{Empirical research and analysis}

Descriptive statistics: Table 1 showed that average of EPS from insurance companies that became sample of this research is 180.78 . It means that on average, insurance companies in 2014-2017 able to generate earn per share around $180,78 \%$. With the minimum value is -49.31 and the maximum is 612.5 . 
Res. J. Applied Sci., 14 (3): 76-83, 2019

Table 1: Statistics descriptive

\begin{tabular}{lrrr}
\hline Variables & \multicolumn{1}{c}{ Mean } & \multicolumn{1}{c}{ Min } & Max \\
\hline EPS & 180.780 & -49.310 & 612.500 \\
PER & 15.530 & -202.900 & 199.100 \\
ROE & 12.210 & -20.650 & 25.230 \\
DAR & 0.530 & 0.170 & 0.830 \\
NPM & 18.760 & -23.900 & 116.400 \\
PBV & 2.060 & 0.110 & 18.520 \\
RBK & 0.570 & -0.464 & 1.026 \\
RPP & 0.145 & 0.005 & 0.444 \\
TATO & 0.330 & 0.109 & 0.705 \\
DER & 1.550 & 0.200 & 5.020 \\
\hline
\end{tabular}

The average PER of the insurance company that became sample of this research is 15.53. It means that on average, market price of share is 15.53 times of the earnings per share. With the minimum value is -202.9 because company has a loss and the maximum value per insurance company is 199.1.

The average of ROE in insurance company is 12.21 . It means that every IDR 100 equity of the shareholder can generate profit IDR 12.21

The average of DAR in insurance company is 0.53 . It means that every 100 of assets, there are IDR 53 debt. It showed that company is in solvable condition.

The average of NPM is 18.76. it means that on average insurance company is able to get a profit from selling activity around $18.76 \%$.

The average of PBV is 2.06 . It means that market price of share in insurance company is 2.06 times of the equity book value. With the minimum of PBV is 0.11 and the maximum is 18.52 .

The average of RBK is 0.57 . It means that every IDR 100 premium that obtained by the insurance company, IDR 57 is defined as a claim expense. The minimum of the $\mathrm{RBK}$ is -0.464 , it showed that premium income is higher than a premium expense, so that, insurance company do not experience loss. With the maximum value is 1,026 . The average of RPP is 0.145 . It means that every IDR 100 net premium on the t period will increasing IDR 114.5 on the $t+1$ period. The minimum value of RPP is 0.005 and the maximum value is 0.444 .

The average of TATO is 0.33 . It showed that every IDR 100 of company's asset can generate IDR 33 in sales. With the minimum value is 0.109 and the maximum is 0.705 .

The average of DER is 1.55. It means that every 100 of equity, there are 155 debt in it. This number showed that company in an unsolvable condition. With the minimum value of DER is 0.2 and the maximum is 5.02 .

The best panel model: From Table 2, it showed that the best model for data panel model in this research is REM.
Table 2: Result of the best panel model

\begin{tabular}{|c|c|c|c|c|}
\hline Test/Crit & & Sign & & \\
\hline Chow & & & & \\
\hline $\begin{array}{l}\text { Cross-sec } \\
\text { LM }\end{array}$ & quare & 0.6486 & & el is CEM \\
\hline Cross-sec & sch Pagan & 0.0826 & & el is REM \\
\hline Variable & Coefficient & & & Prob. \\
\hline$\overline{\mathrm{C}}$ & 0.2094 & & & 0.7885 \\
\hline EPS & -0.0010 & & & 0.8207 \\
\hline PER & 0.0009 & & & 0.6517 \\
\hline ROE & -0.0017 & & & 0.7462 \\
\hline DAR & -0.3352 & & & 0.8238 \\
\hline NPM & 0.0001 & & & 0.9800 \\
\hline PBV & 0.0514 & & & 0.1406 \\
\hline $\mathrm{RBK}$ & 0.0201 & & & 0.9658 \\
\hline RPP & -0.0811 & & & 0.9232 \\
\hline TATO & 0.0074 & & & 0.9914 \\
\hline DER & 0.0860 & & & 0.6225 \\
\hline $\mathrm{R}^{2}$ & 0.1763 & & & \\
\hline F-stat & & & & 0.636 \\
\hline
\end{tabular}

Table 4: The best model panel with data transformation

\begin{tabular}{lcl}
\hline Test/Criteria & Sign & Results \\
\hline $\begin{array}{l}\text { Chow } \\
\text { Cross-section Chi-square }\end{array}$ & 0.0470 & The best model is FEM \\
$\begin{array}{l}\text { Hausman } \\
\text { Cross-section random }\end{array}$ & 0.7605 & The best model is REM \\
$\begin{array}{l}\text { LM } \\
\text { Cross-section Breusch-Pagan }\end{array}$ & 0.0768 & The best model is REM \\
\hline
\end{tabular}

Table 5: reression model transformation data panel

\begin{tabular}{lcrc}
\hline Variables & Coefficient & t-stat. & Prob. \\
\hline c & -3.3690 & -1.006 & 0.3277 \\
EPS & 0.1160 & 0.564 & 0.5795 \\
PER & -0.8660 & -1.137 & 0.2702 \\
ROE & -0.7790 & -1.703 & 0.1056 \\
DAR & -9.0750 & -3.505 & 0.0025 \\
NPM & -0.8820 & -1.083 & 0.2927 \\
PBV & 1.9460 & 2.365 & 0.0294 \\
RBK & -3.4100 & -2.693 & 0.0149 \\
RPP & -0.0430 & -0.220 & 0.8283 \\
TATO & 0.9650 & 1.568 & 0.1342 \\
DER & 1.9030 & 1.507 & 0.1489 \\
R $^{2}$ & 0.6311 & & \\
F-stat & & 3.079 & 0.0018 \\
\hline
\end{tabular}

Regression model data panel: From Table 3, it showed that sign of F-test is $0.636(>0.1)$. It means that this regression model is not the fit model. Further, we need to do the transformations of the data using logarithm natural (ln).

The best panel model with data transformation: Based on Table 4, we know that the best model for panel data transformation is REM.

Regression model panel data transformation: Table 5 showed that the model panel is a fit model with the ability of the explanation is $63.11 \%$. From Table 5 , it will generate a model in: 
Stock return $=-3.37+0.116$

$\begin{array}{lll}\text { EPS }-0.867 & \text { PER }-0.78 & \text { ROE }-9.075 \\ \text { DAR }-0.882 & \text { NPM }+1.947 & \text { PBV }-3.41 \\ \text { RBK }-0.043 & \text { RPP }-0.965 & \text { TATO + 1.903 } \\ \text { DER } & & \end{array}$

This equation showed that: constanta has a value -3.37 with the significance 0.3277 . It means that constanta do not have a meaning. The coefficient regression of EPS is 0.116 with the significance 0.5795 . It means that EPS has a positive effect to stock return but 1 it is not significant.

The coefficient regression of PER is -0.867 with the significance 0.2702 . It means that PER has a negative effect to stock return but it is not significant. The coefficient regression of $\mathrm{ROE}$ is -0.78 with the significance 0.1056 . It means that ROE has a negative effect to stock return but it is not significant.

The coefficient regression of DAR is -9.075 with the significance 0.025 . It means that DAR has a negative significant effect to stock return. If DAR is increasing 1 unit, stock return will be decreasing 9.075 unit.

The coefficient regression of NPM is -0.882 with the significance 0.2927 . It means that NPM has a negative effect to stock return but it is not significant. The coefficient regression of $\mathrm{PBV}$ is 1.947 with the significance 0.0294. It means that PBV has a positive significant effect to stock return. If PBV is increasing 1 unit, stock return will be increasing 1.947 unit.

The coefficient regression of RBK is -3.41 with the significance 0.0149 . It means that $\mathrm{RBK}$ has a negative significant effect to stock return. If RBK is increasing 1 unit, stock return of an insurance company will be decreasing 3.41 unit.

The coefficient regression of RPP is -0.043 with the significance 0.8283 . It means that RPP has a negative effect to stock return but it is not significant. The coefficient regression of TATO is 0.965 with the significance 0.1342 . It means that TATO has a positive effect to stock return but it is not significant.

The coefficient regression of DER is 1.903 with the significance 0.1489 . It means that DER has a positive effect to stock return but it is not significant. Further, it can be conclude as an individually, the independent variables that influence stock return in the insurance company are DAR, $\mathrm{PBV}$ and $\mathrm{RBK}$. With the biggest contribution comes from DAR.

\section{Based on this research}

EPS: The result of this research showed that EPS has a positive effect but it is not significant. The results of this research are in line with the research of Nicky (2008) which states that decreasing of EPS value is indicates that investors does not want to invest their shares in the company and Utami et al. (2015) states that EPS does not have a significant effect on stock returns. But this research is not in line with Vermeuleun (2016) research which conducted research in the period 1994-2013 and the result is EPS has a negative effecr but it is not significant, and Ghi's research in the period 2010-2013 with the result is EPS has a positive effect and significant effect and the research of Al-Salamat and Mustafa (2016) which conducted in the period 2007-2014 where the result is EPS has a negative effect but it is not significant on stock returns.

PER: Based on this research, it find that PER has negative effect but it is not significant on the stock return. The results of this study are in line with the research of Nesa (2015) which states that as a partially PER has negative effect on stock returns but it is not significant on the stock return. But this study is not in line with Ozturk and Karabulut (2017) which conducted research in the period 2008-2016 and the result of this research is PER has a positive significant effect and Gautam (2017) whom conducted research on commercial banks in Nepal showed that PER has a negative significant effect on the stock return and from research by Menike et al. (2015) who conducted a study in 2012 showed that PER has a positive significant effect. Meanwhile, Thuku (2012) who conducted research on listed companies in the Main Market Investments Segments (MIMS) showed that PER has a positive effect but it is not significant on stock returns.

ROE: Based on this research, ROE has a negative effect but it is not significant on the stock return. This is in line with the research by Anwaar (2016) which revealed that increasing of the value of ROE will give an effect of decreasing the value of stock returns. However, this research is not in line with Gunaratne and Anuradha (2017) whom conducted research in the period 1999-2013 and showed that ROE has a positive effect but it is not significant and the research by Har and Ghafar (2015) whom conducted research on plantation companies and showed that ROE has a positive significant effect on stock returns.

DAR: Based on this research, we know that DAR is in line with the hypotheses that have been made. DAR has a negative significant effect on stock returns. If DAR increasing it will give an impact to decreasing of the stock price, so that, the stock return will decreasing. The increasing of DAR show that company's debt is getting 
higher. Increasing of debt will contains the higher risks. In general, investors does not like a risk, so, if the risk increasing, the interest of the investor to stock will decreasing and it will give an impact to the stock price where the stock price will falling down. This finding is in line with the research of Amalia (2017) who also conducted research on insurance companies and similar to the result of the research by Puri and Haryanto (2013) which revealed that the higher use of leverage would interfere with the company's ability to generate profits, so, companies with having a high debt ans it would threatened with bankruptcy.

NPM: Based on this research, it showed that NPM has a negative effect but it si not significant to stock return. This is in line with the research conducted by Adek et al. (2015) which states that the reason of insignificance effect of NPM is because the operating expense value is higher than the sales profit and also due to the characteristics of NPM, that NPM do not show a linear trend for all insurance companies listed on the Indonesia Stock Exchange in 2013. The trend is fluctuating but this research is not in line with Nurhakim et al. (2016) who conducted research in the period 2011-2014 and it showed that NPM has a negative significant effect on stock returns.

PBV: Based on this research, we know that PBV has a was found that PBV has a positive significant effect on stock returns in insurance company. PBV describes price per share when compared to the book value of its equity. The higher PBV is a signal that the company is performing well. This positive signal has an impact to risen of the stock price, so that, stock returns will rise. This is also in line with Nathaniel which states that the smaller value of PBV, price of stock will be going cheaper or underprice compared to the prices of other similar stocks. This condition will also have an impact on decreasing stock returns. This is also in line with the research of Desy and Astohar (2012) which states that increasing in PBV, indicates that the company's stock performance is good. This good performance can affect investors to invest through buying shares in the company.

RBK: Based on this research, we know that RBK is in line with the hypothesis that has been made where RBK has a negative effect on stock returns. RBK describes the underwriting and risk of closing processes that have been carried out by insurance companies. The higher RBK, show the more risk is closed which means the higher the risk of the insurance company. If the company's risk is higher, the interest of investors to invest in the company's shares is getting lower. Low interest of investment from investor will causes the stock prices to fall. When the stock price is fall, it will affect the return. The findings of this research are in line with research conducted by Siswandaru (2006) who examined 10 insurance companies during period 1999-2003 which revealed that $\mathrm{RBK}$ described an experience in closing the risks that had occurred. A high level of claim expense due to certain relatively large claims will threaten the financial condition of the company, thereby increasing the risk for the company. The declining ability of companies to generate profits will declining investor's interest in buying insurance shares and will also increasing the potential for bankruptcy.

RPP: Based on this research, we know that RPP has a negative effect but it is not significant on stock return. This is in line with the research conducted by Amalia (2017) whom conducted research on insurance companies listed on Indonesian Stock Exchange. The result of this research indicates that insurance stock investors in Indonesia does not care about the premiums of insurance, so, premium of insurance do not affect stock prices on the stock. Further, researcher can try to examine the demographic characteristics of stock investors in insurance companies in Indonesia.

TATO: Based on this research, we know that TATO has a positive effect but it is not significant on stock returns. This is not inline from the results of Khotimah and Murtaqi (2015) which states that TATO has a positive significant effect on the research in the food and beverage sector in the period 2003-2012.

DER: Based on this research, we know that DER has a positive effect but it is not significant on the stock return. This result is inline with the research of Petcharabul and Romprasert (2014) which states that there is no influence between DER and stock returns. This research also inline with Adek et al. (2015) which revealed that characteristics of DER and characteristics of stock prices of all insurance companies listed on Indonesia Stock Exchange in 2013 did not show a linear trend, it showed a fluctuating trend. This trend occurs because when DER of the insurance company increasing, it means that the company is not good in managing their equity to pay its debt, this indicates that the company's performance is not efficient and effective. The results of this research is also in line with Astuti (2013) which states that companies whom having a high DER will work, so hard to be able to pay off their debt so that their debt can be repaid. But this research is not in line with Anshika (2017) who conducted research on Banks in the period April 2000 to March 2014. 


\section{CONCLUSION}

Based on the research and discussion, some conclusions can be stated as follows: EPS has a positive effect but it is not significant on stock return in insurance company. PER has a negative effect but it is not significant on stock return in insurance company. ROE has a negative effect but it is not significant on stock return in insurance company. DAR has a negative significant on stock return in insurance company. NPM has a negative effect but it is not significant on stock return in insurance company. PBV has a positive significant effect on stock return in insurance company. RBK has a negative significant effect on stock return in insurance company. RPP has a negative effect but it is not significant on stock return in insurance company. TATO has a positive effect but it is not significant on stock return in insurance company. DER has a negative effect but it is not significant on stock return in insurance company.

\section{RECOMMENDATIONS}

Some of recommendations based on this research as follows: This research used 10 independent variables with $\mathrm{R}$ is $63.11 \%$. This coefficient determination is quite good, but it still can be improved. Further, for the next researcher it is recommended to add or replace the independent variables to be used. This research model can also be tested in other financial industries.

For investors and the potential investors who want to invest in insurance companies, it is recommended to pay attention to the value of DAR or Debt to Asset Ratio. This is because DAR has the biggest and most significant effect on the stock returns compared with 9 other independent variables used on this research.

For insurance companies, to be able to get a high stock return, insurance companies need to pay attention to their financial performance, especially, the DAR ratio. This is because DAR has a negative effect and this is also the biggest variable that influence on stock returns. Management needs to manage company debt and strive for it in a relatively low proportion. This finding also shows that investors in insurance companies in Indonesia are risk averse. Investors does not like risk. Companies that have a high debt face relatively high risks, thereby reducing investor's interest in investing in stocks. This has an impact on decreasing of stock prices and in turn causes stock returns to goes down.

To increase stock prices, so that, the return increases, researchers suggest that if an insurance company adds assets, it is better if the asset is funded with equity, not funded with debt. In other words, insurance companies must be able to maintain a balance between debt and assets.

\section{REFERENCES}

Adek, R., P.B. Marwoto and F. Panjaitan, 2015. Analysis of the effect of Earning Per Share (EPS), Net Profit Margin (NPM), Return on Assets (ROA) and Debt to Equity Ratio (DER) Against Stock Prices in Insurance Companies Listed on the Indonesia Stock Exchange Year 2011-2013. Bus. Financial Accounting Sci. J., 3: $18-28$.

Al-Salamat, W.A. and H.H. Mustafa, 2016. The impact of capital structure on stock return: Empirical evidence from Amman Stock Exchange. Intl. J. Bus. Soc. Sci., 7: 183-196.

Amalia, R., 2017. Financial performance and stock returns: A study of insurance companies on the Indonesia Stock Exchange. J. Bus. Manage., 7: 1-14.

Anshika, 2017. Micro-economic factors affecting stock returns: An empirical study of S\&P BSE bankex companies. Indian J. Econ. Dev., 5: 1-6.

Anwaar, M., 2016. Impact of firm's performance on stock returns (Evidence from Listed Companies of FTSE-100 Index London, UK). Global J. Manag. Bus. Res., 16: 1-10.

Astuti, N.P., 2013. Effect of Earning per Share (EPS), Price Earning Ratio (PER) and Debt to Equity Ratio (DER) against stock returns on insurance companies listed on the Indonesia Stock Exchange (IDX). MBA Thesis, University of Islam Negeri, Pekanbaru, Indonesia.

Desy, A. and Astohar, 2012. Analysis of factors affecting stock returns (case in manufacturing companies that go public on the IDX for the year period 2005-2009). J. Appl. Manage. Accounting, 3: $1-15$.

Eduardus, T., 2001. Investment Analysis and Portfolio Management. 1st Edn., BPFE, Yogyakarta, Indonesia,.

Gautam, R., 2017. Impact of firm specific variables on stock price volatility and stock returns of Nepalese commercial banks. Int. J. Res. Bus. Stud. Manag., 4: $33-44$.

Gunadi, G.G. and I.K.W. Kesuma, 2015. [Effect of ROA, DER, EPS on the Stock Exchange Food and Beverage Company (In Indonesian)]. E J. Manage. Unud., 4: 1636-1647.

Gunaratne, Y.M.C. and P.N.S. Anuradha, 2017. Value relevance of accounting information in explaining stock returns in Sri Lanka. Intl. J. Bus. Manage., 12: 223-233. 
Har, W.P. and M.A.A. Ghafar, 2015. The impact of accounting earnings on stock returns: The case of Malaysia's plantation industry. Intl. J. Bus. Manage., 10: 155-165.

Irham, F. and Y.L. Hadi, 2009. [Portfolio Theory and Investment Analysis]. 1st Edn., Alfabeta, Bandung, Indonesia, (In Indonesian).

Khotimah, K. and I. Murtaqi, 2015. The fundamental analysis of indonesian stock return case study: Listed public companies in sub sector food and beverage for the period 2003-2013. J. Bus. Manage., 4: 95-104.

Menike, L.M.C.S., P.M. Dunusinghe and A. Ranasinghe, 2015. Macroeconomic and firm specific determinants of stock returns: A comparative analysis of stock markets in Sri Lanka and in the United Kingdom. J. Finance Accounting, 3: 86-96.

Nesa, A., 2015. Analysis of factors affecting stock returns (Case Study of automotive and component sub sector companies listed on the Indonesia stock exchange period 2010-2014. Perbanas Rev., 1: 72-86.

Ngaisah, S., 2008. Effect of profitability and savings ratio on stock returns for companies registered in the Jakarta Islamic Index in 2004-2006. Master Thesis, UIN Sunan Kalijaga Yogyakarta, Indonesia.

Nicky, N.S.D., 2008. [Analysis of factors that affect stock returns (study of real estate and property stocks on the Indonesia Stock Exchange 2004-2006 period)]. Ph.D Thesis, Diponegoro University, Semarang, Indonesia. (In Indonesian)

Noor, H.F., 2014. Investment, Financial Management and Community Economic Development. Mitra Wacana Media, Jakarta, Indonesia. (In Indonesian).

Nurhakim, A., I. Yunita and A. Iradianty, 2016. The effect of profitability and inflation on stock return at pharmaceutical industries at BEI in the period of 2011-2014. Asia Pasific J. Adv. Bus. Soc. Stud., 2: 206-208.

Ozturk, H. and T.A. Karabulut, 2017. The relationship between earnings-to-price, current ratio, profit margin and return: An empirical analysis on Istanbul Stock Exchange. Accounting Finance Res., 7: 109-115.
Petcharabul, P. and S. Romprasert, 2014. Technology industry on financial ratios and stock returns. J. Bus. Econ., 5: 739-746.

Puri, W. and A.M. Haryanto, 2013. Analysis of the effect of fundamental factors and trading volume on stock returns (Case Study in Real Estate and Property Companies Registered on the Indonesian Stock Exchange Period 2007-2010). Diponegoro J. Manage., 2: 1-11.

Rahmawati, 2012. Financial Accounting Theory. Graham Publishing Company, Yogyakarta, Indonesia,

Rita, R., R. Wulan and Hendro, 2014. Effect of profitability ratio, activity ratio, market ratio, firm size, interest rate and exchange rate against stock returns (empirical study on food and beverage companies in Indonesia Stock Exchange period 2008-2011). J. Bus. Manage., 4: 79-91.

Siswandaru, K., 2006. Analysis of the influence of SBI early warning system and interest rate ratios on stock prices (empirical study on insurance companies at BEJ year 1999-2003). MBA Thesis, Diponegoro University, Semarang, Indonesia.

Suad, H. and E. Pudjiastuti, 2015. Fundamentals of Financial Management. 7th Edn., UPP STIM YKPN, Yogyakarta, Indonesia,

Sutrisno, 2000. Financial Management Theory, Concepts and Applications. 1st Edn., Ekonisia, Yogyakarta, Indonesia,

Thuku, M.M.A., 2012. Study of the factors influencing stocks returns at the NSE. MBA Thesis, University of Nairobi, Nairobi, Kenya.

Utami, W.R., S. Hartoyo and T.N.A. Maulana, 2015. The effect of internal and external factors on stock return: Empirical evidence from the Indonesian construction subsector. Asian J. Bus. Manage., 3: 370-377.

Vermeulen, M., 2016. Fundamental factors influencing returns of shares listed on the Johannesburg Stock Exchange in South Africa. J. Econ. Financial Sci., 9: 426-435. 